\title{
UREASE ACTIVITY AND NITROGEN MINERALIZATION KINETICS AS AFFECTED BY TEMPERATURE AND UREA INPUT RATE IN SOUTHERN CHILEAN ANDISOLS
}

\section{Efecto de la temperatura y dosis de fertilización con urea sobre la actividad ureasa y cinética de mineralización de nitrógeno en Andisoles del Sur de Chile}

\author{
Paula Cartes ${ }^{1}$, Alejandra A. Jara ${ }^{2}$, Rolando Demanet ${ }^{1}$ and María de la Luz Mora ${ }^{3} *$ \\ ${ }^{1}$ Instituto de Agroindustria, Universidad de La Frontera \\ ${ }^{2}$ Departamento de Ciencias Químicas, Facultad de Ingeniería, Ciencias y Administración, \\ Universidad de La Frontera \\ ${ }^{3}$ Centro de Ciencia y Biotecnología de Recursos Naturales, Universidad de La Frontera. \\ * Corresponding author: mariluz@ufro.cl \\ Address: Av. Francisco Salazar 01145, P.O.Box 54-C, Temuco, Chile
}

\begin{abstract}
Incubation studies were carried out to evaluate the effect of temperature and urea supply level on both the urease activity and the kinetics of $\mathrm{N}$ mineralization in two Andisols of Southern Chile. Our results showed that urease activity was higher in Piedras Negras soil (PNS) than Freire soil (FS) at 24 and 48 h, and the enzyme was activated when the temperature increased from 5 to $21^{\circ} \mathrm{C}$. Urease activity followed a simple Michaelis-Menten kinetics. In PNS, the Michaelis Menten constant $\left(K_{m}\right)$ decreased, whereas the maximum enzyme reaction velocity $\left(V_{\max }\right)$ and the catalytic efficiency increased when the temperature was raised up to $21^{\circ} \mathrm{C}$ at 24 and $48 \mathrm{~h}$ of soil incubation. In FS, urease activity was the highest at $24 \mathrm{~h}$, and it decreased at $48 \mathrm{~h}$ as a consequence of substrate depletion. On the other hand, the kinetics of $\mathrm{N}$ mineralization data fitted nearly to a single exponential model. At early stages of incubation, similar amounts of mineralized $\mathrm{N}\left(N_{\min }\right)$ were found in both soils. However, $N_{\min }$ was 27 to $64 \%$ higher in PNS than FS at the end of the experiment. These results had direct relation with the soil organic matter content, temperature and urea input rates. In PNS, we observed that 47 to $80 \%$ of $N_{\min }$ remained as $\mathrm{NH}_{4}{ }^{+} \mathrm{N}$, whereas in $\mathrm{FS} \mathrm{NO}_{3}{ }^{-} \mathrm{N}$ represented between 80 and $96 \%$. Such differences in the dynamics of $\mathrm{N}$ transformation were in accordance with the $\mathrm{pH}$ variation registered during the experimental period. These facts have practical implications for agricultural systems management in a particular location, because of the dynamics of $\mathrm{N}$ mineralization in Andisols is mainly controlled by the organic matter content and biological properties of soils, as well as by the temperature and urea input rate to the soil-plant system.
\end{abstract}

Keywords: urease activity, $\mathrm{N}$ mineralization, urea, Andisols

\section{RESUMEN}

Se realizaron estudios de incubación para evaluar el efecto de la temperatura y niveles de suministro de urea sobre la actividad ureasa y la cinética de mineralización de $\mathrm{N}$ en dos Andisoles del Sur de Chile. Nuestros resultados mostraron que la actividad ureasa fue más alta en el suelo Piedras Negras (PNS) que en el suelo Freire (FS) a 24 y 48 h, y la enzima fue activada cuando la temperatura incrementó desde 5 a $21^{\circ} \mathrm{C}$. La actividad ureasa siguió una cinética simple de Michaelis-Menten. En PNS, la constante de Michaelis-Menten $\left(K_{m}\right)$ 
disminuyó, mientras que la velocidad máxima de reacción de la enzima $\left(V_{\max }\right)$ y la eficiencia catalítica aumentaron cuando la temperatura fue elevada hasta $21^{\circ} \mathrm{C}$ a 24 y $48 \mathrm{~h}$ de incubación del suelo. En FS, la actividad ureasa fue la más alta a las 24 h, y ésta disminuyó a las $48 \mathrm{~h}$ como consecuencia del agotamiento del sustrato. Por otra parte, los datos de cinética de mineralización de $\mathrm{N}$ estrechamente se ajustaron a un modelo exponencial simple. A etapas tempranas de la incubación, cantidades similares de $\mathrm{N}$ mineralizado $\left(N_{\min }\right)$ fueron encontradas en ambos suelos. Sin embargo, $N_{\min }$ fue 27 a $64 \%$ más alto en PNS que FS al final del experimento. Estos resultados tuvieron directa relación con el contenido de materia orgánica del suelo, la temperatura y el nivel suministro de urea. En PNS, nosotros observamos que 47 a $80 \%$ de $N_{\min }$ permaneció como $\mathrm{NH}_{4}{ }^{+}-\mathrm{N}$, mientras que en $\mathrm{FS} \mathrm{NO}_{3}{ }^{-} \mathrm{N}$ representó entre 80 y $96 \%$. Tales diferencias en la dinámica de transformación de $\mathrm{N}$ estuvieron de acuerdo con la variación del $\mathrm{pH}$ registrada durante el período experimental. Estos hechos tienen implicancias prácticas para el manejo de los sistemas agrícolas en una localidad en particular, debido a que la dinámica de la mineralización de $\mathrm{N}$ en Andisoles es principalmente controlada por el contenido de materia orgánica y las propiedades biológicas de suelos, así como por la temperatura y el nivel de suministro de urea al sistema suelo-planta.

Palabras claves: actividad ureasa, mineralización de N, urea, Andisoles

\section{INTRODUCTION}

Nitrogen $(\mathrm{N})$ is an essential element for plant nutrition, being one of the most important factors that limits crop and pasture yields, but it is also an issue of global environmental concern. In intensive agricultural systems, farmers often supply amounts of $\mathrm{N}$-fertilizers larger than the quantity required to achieve the optimum yield. According with Lemaire et al. (2008) the reason leading farmers to apply large amounts of $\mathrm{N}$-fertilizers is the unpredictable soil $\mathrm{N}$ supply in terms of soil type, previous crop management and climate variability.

In Chile, cropping and grasslands systems are commonly fertilized with urea at $\mathrm{N}$ supply ranging from 45 to $300 \mathrm{~kg} \mathrm{~N} \mathrm{ha}^{-1}$ (Ordoñez, 2003; Mora et al., 2004; Alfaro and Salazar, 2005; Alfaro et al., 2006; Mora et al., 2007). The application of $\mathrm{N}$-fertilizers over the plant optimal demand leads to significant environmental consequences due to $\mathrm{N}$ losses by leaching and gaseous emissions (González et al., 1995; Novoa et al., 2000; Mora et al, 2004; Alfaro et al., 2005; 2006). This issue and the continuous increase of the $\mathrm{N}$-fertilizers price make necessary to develop more efficient agricultural management practices through the better comprehension of the processes that govern both the transformation and the availability of $\mathrm{N}$ in the soil.

In the soil-plant system, $\mathrm{N}$ availability mainly depends on the mineralization of organic- $\mathrm{N}$ into inorganic- $\mathrm{N}$ forms from soil organic matter, crop residues, manures or sludge amendments and urea-based fertilizers. When urea is added to the soil, it is firstly hydrolyzed to $\mathrm{NH}_{4}{ }^{+}-\mathrm{N}$ by urease enzymes (1), and in a second step $\mathrm{NH}_{4}{ }^{+}-\mathrm{N}$ is oxidized to $\mathrm{NO}_{3}{ }^{-}-\mathrm{N}$ by the nitrification process (2 and 3 ). Thus, the pool of net mineralized $\mathrm{N}$ comprises the sum of $\mathrm{NH}_{4}{ }^{+}-\mathrm{N}$ and $\mathrm{NO}_{3}{ }^{-}-\mathrm{N}$ in the soil.

$$
\mathrm{CO}\left(\mathrm{NH}_{2}\right)_{2(s)}+3 \mathrm{H}_{2} \mathrm{O}_{(l)} \longrightarrow 2 \mathrm{NH}_{4(a q)}^{+}+\mathrm{HCO}_{3(a q)}^{-}+\mathrm{OH}_{(a q)}^{-}
$$




$$
\begin{aligned}
& \mathrm{NH}_{4(a q)}^{+}+3 / 2 \mathrm{O}_{2(g)} \longrightarrow \mathrm{NO}_{2(a q)}^{-}+2 \mathrm{H}_{(a q)}^{+}+\mathrm{H}_{2} \mathrm{O}_{(l)} \\
& \mathrm{NO}_{2(a q)}^{-}+1 / 2 \mathrm{O}_{2(g)} \longrightarrow \mathrm{NO}_{3(a q)}^{-}
\end{aligned}
$$

It is well known that the hydrolyzing activity of urease follows the Michaelis-Menten kinetics, and it is influenced by several factors including the soil type, organic matter content, temperature, soil moisture, $\mathrm{pH}$ and the amount of added N (Yadav et al., 1987; Cabrera et al., 1991; Wang et al., 2004a). Changes in the urease activity can be used as an indirect indicator of the variation in the pool of potentially available $\mathrm{N}$ in a soil at the current weather conditions, but they are not useful to predict the amount of potentially mineralizable $\mathrm{N}\left(N_{0}\right)$.

Different approaches have been employed to evaluate the kinetics of $\mathrm{N}$ mineralization as indicators of $\mathrm{N}$ availability over the time in soils. In fact, single exponential models have been successfully applied to describe $\mathrm{N}$ mineralization by relating the $N_{0}$ from a single compartment with the incubation time (i.e. Stanford and Smith, 1972; Cabrera, 1993; Wang et al, 2003; Camargo et al., 2004; Pereira et al., 2005). Double exponential models that includes two compartments of $N_{0}$, each representing organic pools that differ in their resistance to decomposition, have also been widely used to describe $\mathrm{N}$ mineralization dynamics (Molina et al., 1980; Deans et al., 1986; Wang et al., 2004b; Cabrera et al., 2005). Several studies showed that double exponential models are better than the single ones to describe $\mathrm{N}$ mineralization (Cabrera and Kissel, 1988; Dou et al., 1996; Wang et al., 2004b). However, Camargo et al. (2002) concluded that double models may be superparametrized and they rejected the hypothesis about the presence of two $\mathrm{N}$ compartments susceptible to be mineralized by using data of a 32 week soil incubation study. Moreover, Camargo et al. (2004) indicated that to test this hypothesis it is necessary to make one to two years incubation studies in order to evaluate the possible advantages of double over single exponential models.

Although many kinetic studies about the urea mineralization have been conducted (Kumar and Wagenet, 1984; Makkar and Singh, 1986; Rodríguez et al., 2005), to our knowledge there is a dearth of reports showing the changes of the kinetics of $\mathrm{N}$ mineralization in relation to chemical properties in ash derived soils like Andisols. Thus, a better understanding of the mineralization process of urea-based fertilizers in Andisols through the evaluation of kinetic changes will contribute to the development of fertilization strategies to increase the efficiency of use of $\mathrm{N}$-fertilizers and minimize the negative impact on the environment.

The aims of this study were: (i) to evaluate the effect of time, temperature and urea input rates on urease activity and (ii) to determine the kinetics of $\mathrm{N}$ mineralization at different combinations of temperature and urea input rates in Andisols of Southern Chile under laboratory conditions.

\section{MATERIALS AND METHODS}

Andisols samples from Piedras Negras (PNS; $40^{\circ} 20^{\prime} \mathrm{LS}$ and $72^{\circ} 35^{\prime} \mathrm{LW}$ ) and Freire (FS; $38^{\circ} 50^{\prime} \mathrm{LS}$ and $72^{\circ} 42^{\prime} \mathrm{LW}$ ) soil Series were collected at $0-20 \mathrm{~cm}$ depth to carry out incubation studies. The samples were air-dried, sieved to $2 \mathrm{~mm}$ and the soil chemical composition as well as the microbial biomass nitrogen (MBN) were determined (Table 1). Soil $\mathrm{pH}$ was measured by potentiometry in a 1:2.5 (w/v) soil/distilled water suspension. Phosphorus was extracted by the Olsen bicarbonate 
Table 1. Chemical properties and biological parameters of Chilean Andisols belonging to the Piedras Negras and Freire soil Series

Cuadro 1. Propiedades químicas y parámetros biológicos de Andisoles chilenos pertenecientes a las Series de suelo Piedras Negras y Freire

\begin{tabular}{|c|c|c|c|c|c|c|c|c|}
\hline Soil & $\begin{array}{c}\mathbf{p H} \\
\left(\mathbf{H}_{2} \mathbf{O}\right)\end{array}$ & $\begin{array}{c}\text { Organic } \\
\mathbf{m a t t e r} \\
\left(\mathbf{g ~ k g}^{-1}\right)\end{array}$ & $\begin{array}{c}\mathbf{N} \\
\left(\mathbf{m g ~ k g}^{-1}\right)\end{array}$ & $\begin{array}{c}\text { Olsen } \mathbf{P} \\
\left(\mathbf{m g ~ k g}^{-1}\right)\end{array}$ & $\begin{array}{c}\text { Exchangeable } \\
\text { cations } \\
\left(\mathbf{c m o l}_{\mathbf{~}} \mathbf{k g}^{-1}\right)\end{array}$ & $\begin{array}{c}\text { Exchangeable } \\
\mathbf{A l} \\
\left(\mathbf{c m o l}_{\mathbf{~}} \mathbf{~ k g}^{-1}\right)\end{array}$ & $\begin{array}{c}\text { Al } \\
\text { Saturation } \\
(\%)\end{array}$ & $\begin{array}{c}\text { MBN } \\
\left(\mathbf{m g ~ k g}^{-1}\right)\end{array}$ \\
\hline $\begin{array}{c}\text { Piedras } \\
\text { Negras } \\
\text { (PNS) }\end{array}$ & $5.43 \pm 0.10$ & $220 \pm 10$ & $48.5 \pm 0.5$ & $2 \pm 1$ & $1.12 \pm 0.05$ & $0.24 \pm 0.02$ & $17.6 \pm 0.6$ & $35 \pm 5$ \\
\hline $\begin{array}{c}\text { Freire } \\
\text { (FS) }\end{array}$ & $5.61 \pm 0.08$ & $170 \pm 6$ & $51.7 \pm 0.9$ & $16 \pm 0.8$ & $10.62 \pm 0.09$ & $0.05 \pm 0.01$ & $0.5 \pm 0.1$ & $20 \pm 2$ \\
\hline
\end{tabular}

method and analyzed by the Murphy and Riley (1962) method. Organic matter was estimated by wet digestion with a modified Walkley-Black procedure. Exchangeable cations $(\mathrm{Ca}, \mathrm{Mg}, \mathrm{Na}$ and $\mathrm{K}$ ) were extracted with $1 \mathrm{M} \mathrm{CH}_{3} \mathrm{COONH}_{4}$ at $\mathrm{pH} 7.0$ and analyzed by Flame Atomic Absorption Spectrophotometry (FAAS). Exchangeable aluminium (Al) was extracted with $1 \mathrm{M}$ $\mathrm{KCl}$ and analyzed by FAAS. Microbial biomass $\mathrm{N}$ was determined by the fumigation-extraction method (Vance et al., 1987), and the amount of MBN was measured by the oxidation of a $\mathrm{N}$ reagent to ninhydrin (Albiach et al., 2003).

\section{Incubation experiments}

We carried out two incubation experiments. In the first study, we evaluated the effect of both the $\mathrm{N}$ supply level and in the temperature on urease activity, and the second one we determined the kinetics of $\mathrm{N}$ mineralization as function of urea application at different temperatures.

In the first experiment, duplicate $100 \mathrm{~g}$ soil samples were treated with urea at rates equivalent to field applications of 0,100 , 200, 400 and $800 \mathrm{~kg} \mathrm{~N}^{-1}$. The samples were incubated in plastic bags at 5, 10 and $21{ }^{\circ} \mathrm{C}$ under aerobic conditions, and subsamples were taken at 24 and $48 \mathrm{~h}$ to determine urease activity. Urease activity was assayed by the modified method of Nannipieri et al. (1980).
Briefly, $4 \mathrm{~mL}$ of $0.1 \mathrm{M}$ phosphate buffer $(\mathrm{pH} 7.1)$ and $1 \mathrm{~mL}$ of $1.067 \mathrm{M}$ urea were added to $1 \mathrm{~g}$ soil samples. The samples were incubated at 5,10 and $21^{\circ} \mathrm{C}$ for $2 \mathrm{~h}$, and thereafter, $5 \mathrm{~mL}$ of $2 \mathrm{M} \mathrm{KCl}$ were added to terminate the reaction. The $\mathrm{N}-\mathrm{NH}_{4}{ }^{+}$was determined by ion selective electrode. Data from the urease activity were fitted to the Michaelis-Menten equation to calculate the Michaelis-Menten constant $\left(K_{m}\right)$ and the maximum enzyme reaction velocity $\left(V_{\max }\right)$. In the second incubation experiment, duplicate $200 \mathrm{~g}$ soil samples were incubated in plastic bags at three temperatures $(5,10$ and $21^{\circ} \mathrm{C}$ ) for 25 days under aerobic conditions. Three urea input rates, equivalent to 0,100 and $200 \mathrm{~kg} \mathrm{~N} \mathrm{ha}^{-1}$ were applied. The cumulative amount of mineralized $\mathrm{N}$ $\left(\mathrm{NH}_{4}{ }^{+}-\mathrm{N}\right.$ and $\left.\mathrm{NO}_{3}{ }^{-}-\mathrm{N}\right)$ was determined by sampling in the first day at 2, 4, 8, $12 \mathrm{~h}$ and $24 \mathrm{~h}$ after the beginning of incubation. Thereafter, samplings were made at 2, 5, 10, 15,20 and $25 \mathrm{~d}$. Inorganic- $\mathrm{N}$ in the soil samples was extracted with $2 \mathrm{M} \mathrm{KCl}$. In extracts, $\mathrm{NH}_{4}{ }^{+}-\mathrm{N}$ and $\mathrm{NO}_{3}{ }^{-}-\mathrm{N}$ were determined with $\mathrm{MgO}$ and Devarda alloy distillation, respectively.

In order to evaluate the kinetic of $\mathrm{N}$ mineralization, inorganic- $\mathrm{N}$ data $\left(\mathrm{NH}_{4}{ }^{+}-\mathrm{N}\right.$ plus $\left.\mathrm{NO}_{3}^{-}-\mathrm{N}\right)$ several single exponential model were evaluated (Jones, 1984; Camargo et al., 2004). The best fit was obtained with the model proposed by Jones (1984): 


$$
N_{\min }=N_{o}(1-(1-k / h) \exp (-k t))
$$

where $N_{\min }$ is the cumulative amount of inorganic- $\mathrm{N}$ at time $\mathrm{t}, \mathrm{h}$ and $\mathrm{k}$ are empirical constants and $\mathrm{N}_{\mathrm{O}}$ is the potentially mineralizable $\mathrm{N}$.

\section{RESULTS AND DISCUSSION}

Kinetics of urease activity in Andisols The effects of time and temperature on urease activity were evaluated at urea supply level equivalent to field applications from 0 to $800 \mathrm{~kg} \mathrm{~N} \mathrm{ha}^{-1}$ in PNS and FS. In both soils, urease activity followed a simple Michaelis-Menten kinetics, in which the enzyme activity increased with the amount of urea applied (Figure 1). PNS registered a higher urease activity than FS at 24 and $48 \mathrm{~h}$ of soil incubation. Several studies have demonstrated that the increase of both the $\mathrm{pH}$ and the organic matter content activate the urease enzyme in soils (Frankenberger et al, 1983; Antil et al., 1992; Mahata and Antil, 2004). From our results, it can be inferred that no great influence of the soil $\mathrm{pH}$ on urease activity occurred, since the initial $\mathrm{pH}$ value of FS was about 0.2 units greater than that of PNS (Table 1). Nevertheless, both the higher organic matter content and MBN of PNS compared with FS, may explain the highest activation of the urease enzyme, irrespective of the incubation temperature (Figure 1).

A differential activation of urease was also observed by the effect of incubation time in each soil. Thus, the urease activity increased in PNS as the incubation time increased from 24 to $48 \mathrm{~h}$ at each temperature evaluated. In FS, an inhibition of urease occurred after $48 \mathrm{~h}$ at 10 and $21^{\circ} \mathrm{C}$, whereas at $5^{\circ} \mathrm{C}$ the enzyme activity increased.

Likewise, urease enzyme was activated when the temperature increased from 5 to $21^{\circ} \mathrm{C}$ in both soils, but at $48 \mathrm{~h}$ the opposite behavior was observed in FS. In fact, Table 2 shows that the Michaelis-Menten constant
$\left(K_{m}\right)$ decreased and the maximum enzyme reaction velocity $\left(V_{\max }\right)$ increased with the raise of temperature at $24 \mathrm{~h}$ for PNS and FS and $48 \mathrm{~h}$ for PNS. Furthermore, at 24 and $48 \mathrm{~h}$ of PNS incubation, the catalytic efficiency of the enzyme reaction $\left(V_{\max } / K_{m}\right)$ increased 56.1 and $29.4 \%$, respectively, with the increase of temperature from 5 to $21{ }^{\circ} \mathrm{C}$. In FS, the $V_{\max } / K_{m}$ ratio increased 3.2 times at the highest temperature after $24 \mathrm{~h}$ of incubation, whereas $44.1 \%$ of reduction in the catalytic efficiency was observed later.

The decrease of both the urease activity and the $V_{\max } / K_{m}$ ratio at $48 \mathrm{~h}$ of FS incubation suggest that most of applied urea was hydrolyzed before $24 \mathrm{~h}$ at 10 and $21^{\circ} \mathrm{C}$. In contrast, the activation of urease and the slight changes in catalytic efficiency in PNS by effect of the temperature and incubation time indicate that soil urea concentration was not a limiting factor for the enzyme activity. Indeed, previous reports have shown that the addition of urea to soils with high organic matter content activates urease enzyme (Han et al., 2004) due to the stimulation of soil microbial biomass by the effect of the N-added (Blagodatsky et al. 1998).

\section{Kinetics of $N$ mineralization as affected by temperature and urea supply level}

The kinetics of $\mathrm{N}$ mineralization was evaluated for 25 days at different $\mathrm{N}$-supply levels (equivalent to 0,100 and $200 \mathrm{~kg} \mathrm{~N}$ $\mathrm{ha}^{-1}$ ) and temperatures $\left(5,10\right.$ and $21^{\circ} \mathrm{C}$ ). Experimental data of inorganic-N concentration $\left(\mathrm{NH}_{4}^{+}-\mathrm{N}\right.$ plus $\left.\mathrm{NO}_{3}^{-}-\mathrm{N}\right)$ closely fitted to the single exponential model used to evaluate mineralized $\mathrm{N}$ in $\mathrm{FS}\left(\mathrm{R}^{2}=0.69\right.$ $0.96)$ and PNS $\left(\mathrm{R}^{2}=0.86-0.99\right)$. For each soil, the time-dependent kinetics of $\mathrm{N}$ mineralization exhibited a two phase pattern: the amount of mineralized $\mathrm{N}\left(N_{\text {min }}\right)$ increased linearly with time at early stages, and the slope of the time-response curve later decreased (Figure 2 and 3). Previous reports have demonstrated that the addition of Nfertilizers has the potential to stimulate soil $\mathrm{N}$ mineralization (Rasmussen et al., 1998; Kolberg et al., 1999; Yan et al., 2006). 

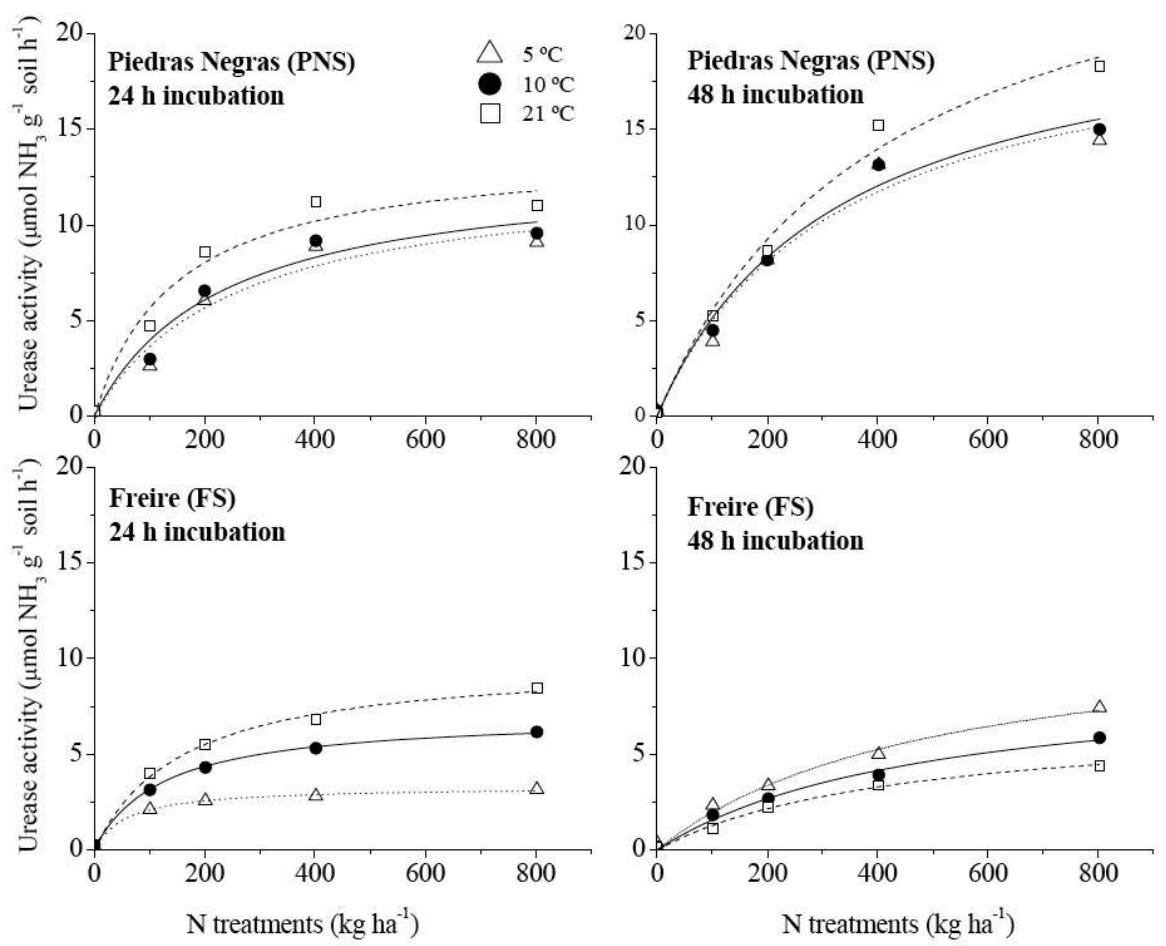

Figure 1: Urease activity in Piedras Negras soil (PNS) and Freire soil (FS) at 24 and 48 $\mathrm{h}$ under different temperatures of incubation $\left(5,10\right.$ and $\left.21^{\circ} \mathrm{C}\right)$ and urea input rates equivalent to applications from 0 to $800 \mathrm{~kg} \mathrm{~N} \mathrm{ha}^{-1}$.

Figura 1: Actividad ureasa en el suelo Piedras Negras (PNS) y en el suelo Freire (FS) a 24 y $48 \mathrm{~h}$ bajo diferentes temperaturas de incubación $\left(5,10\right.$ y $\left.21^{\circ} \mathrm{C}\right)$ y dosis de aplicación de urea equivalentes a aplicaciones desde 0 a $800 \mathrm{~kg} \mathrm{~N} \mathrm{ha}^{-1}$.

In fact, inorganic-N concentration was raised in each soil with the rate of urea application from 0 to $200 \mathrm{~kg} \mathrm{~N} \mathrm{ha}^{-1}$.

Only slight differences in the amount of $N_{\min }$ were detected between PNS and FS at the first stages of soil incubation. However, $N_{\min }$ was 27 to $64 \%$ higher in PNS than FS at the end of the experiment, and the differences in $\mathrm{N}$ mineralization were more noticeable without $\mathrm{N}$ application. These results agreed with the fact that the pool of potentially mineralizable $\mathrm{N}\left(N_{o}\right)$ was 20-40 \% smaller in FS compared with PNS at all N supply levels (Figure 4). Consequently, it can be assumed that most of readily mineralizable $\mathrm{N}$ was transformed to inorganic-N by soil microorganisms in the short-term in FS, and therefore $N_{O}$ became depleted at early stages of the experiment.

Moreover, when the kinetic model was applied to estimate the annual amount of $\mathrm{N}$ mineralized in each soil, we found that $N_{\min }$ values for FS ranged from 44.2 to $72.3 \mathrm{~kg}$ $\mathrm{N} \mathrm{ha}^{-1} \mathrm{yr}^{-1}$ and for PNS from 100.7 to 155.7 $\mathrm{kg} \mathrm{N} \mathrm{ha}{ }^{-1} \mathrm{yr}^{-1}$, which denote significant differences in the $\mathrm{N}$ mineralization rates among both soils across the year. Previously, Matus and Rodríguez (1994) reported N mineralization rates between 30 and $130 \mathrm{~kg}$ $\mathrm{N} \mathrm{ha}^{-1} \mathrm{yr}^{-1}$ depending on organic $\mathrm{N}$ inputs in Chilean Andisol. They also showed a 
Table 2. Kinetics parameters of urease activity in Piedras Negras soil (PNS) and Freire soil (FS) calculated from the Michaelis-Menten equation at 5, 10 and $21{ }^{\circ} \mathrm{C}$.

Cuadro 2. Parámetros cinéticos de la actividad ureasa en el suelo Piedras Negras (PNS) y en el suelo Freire (FS) calculados desde la ecuación de Michaelis-Menten a 5, 10 y $21{ }^{\circ} \mathrm{C}$

\begin{tabular}{|c|c|c|c|c|c|c|}
\hline Soil Series & $\begin{array}{l}\text { Incubation time } \\
\text { (h) }\end{array}$ & $\begin{array}{c}\text { Temperature } \\
\left({ }^{\circ} \mathrm{C}\right)\end{array}$ & $\begin{array}{c}V_{\max } \\
\left(\mu \mathrm{mol} \mathrm{NH} \mathrm{g}^{\prime} \text { soil } \mathrm{h}^{-1}\right)\end{array}$ & $\begin{array}{c}K_{\mathrm{m}} \\
\left(\mu \mathrm{mol}^{\mathrm{kg}}{ }^{\prime} \text { soil }\right)\end{array}$ & $V_{\max } / K_{m}$ & $R^{2}$ \\
\hline \multirow{6}{*}{$\begin{array}{c}\text { Piedras Negras } \\
\text { (PNS) }\end{array}$} & & 5 & 12.8 & 11.2 & 1.14 & 0.955 \\
\hline & 24 & 10 & 13.1 & 10.2 & 1.28 & 0.963 \\
\hline & & 21 & 15.5 & 8.7 & 1.78 & 0.963 \\
\hline & & 5 & 25.1 & 21.0 & 1.19 & 0.963 \\
\hline & 48 & 10 & 25.4 & 20.5 & 1.23 & 0.977 \\
\hline & & 21 & 28.6 & 18.6 & 1.54 & 0.997 \\
\hline \multirow{6}{*}{$\begin{array}{c}\text { Freire } \\
\text { (FS) }\end{array}$} & & 5 & 4.3 & 6.7 & 0.64 & 0.901 \\
\hline & 24 & 10 & 7.0 & 5.4 & 1.30 & 0.996 \\
\hline & & 21 & 8.4 & 4.1 & 2.05 & 0.971 \\
\hline & & 5 & 10.9 & 18.4 & 0.59 & 0.985 \\
\hline & 48 & 10 & 9.1 & 20.6 & 0.44 & 0.991 \\
\hline & & 21 & 6.9 & 21.1 & 0.33 & 0.995 \\
\hline
\end{tabular}

close relationship between $\mathrm{N}$ mineralization and the soil organic matter content, which is in agreement with our results. Furthermore, it has been suggested that $\mathrm{N}$ mineralization rates strongly depend on the degree of $\mathrm{C}$ saturation in clays and silt particles (Matus and Maire, 2000; Matus et al., 2008), which in turn determine the soil capacity to protect the organic matter against decomposition (Six et al., 2002). In our study, the direct relation of $N_{\min }$ with the soil organic matter content appear to be a consequence of higher degree of C saturation in PNS than in FS. Indeed, in highly saturated soils, free organic matter increase because there is a limit for soil organic matter accumulation on clay minerals (Hassink, 1997). Therefore, further studies are necessary to elucidate the role of $\mathrm{C}$-saturation on the stabilization of soil organic matter in order to estimate more accurately the contribution of organic matter to the plant $\mathrm{N}$ mineral nutrition in Chilean Andisols.

On the other hand, non effect of the incubation temperature on the dynamics of
$\mathrm{N}$ transformation (ammonification and nitrification) were detected in FS without $\mathrm{N}$ application, whereas in PNS the raise of temperature from 5 to $21^{\circ} \mathrm{C}$ increased slightly the $\mathrm{NO}_{3}{ }^{-} \mathrm{-N}$ concentration at late stages of the experiment. However, when 100 or 200 $\mathrm{kg} \mathrm{N} \mathrm{ha}{ }^{-1}$ were applied, an increase of temperature up to $21{ }^{\circ} \mathrm{C}$ accelerated the oxidation of $\mathrm{NH}_{4}^{+}-\mathrm{N}$ to $\mathrm{NO}_{3}^{-}-\mathrm{N}$ in both soils. This fact was as expected because it is well known that the activity of nitrifiers is positively regulated by the increase of soil temperature (Nieder and Benbi, 2008).

Figures 2 and 3 also show that urea addition (100 or $200 \mathrm{~kg} \mathrm{~N} \mathrm{ha}^{-1}$ ) increased the rate of urea hydrolysis and delayed the nitrification process in both soils. We observed that more $\mathrm{N}$ was mineralized in PNS with respect to FS, which is in agreement with our results about the kinetics of urease activity (Figure 1; Table 2). Nevertheless, urea hydrolysis to $\mathrm{NH}_{4}{ }^{+}-\mathrm{N}$ and the subsequent nitrification from $\mathrm{NH}_{4}{ }^{+}-\mathrm{N}$ to $\mathrm{NO}_{3}{ }^{-}-\mathrm{N}$ were faster in $\mathrm{FS}$ than in PNS. In FS most of applied urea was hydrolyzed in the short-term (0 to $48 \mathrm{~h}$ ), 

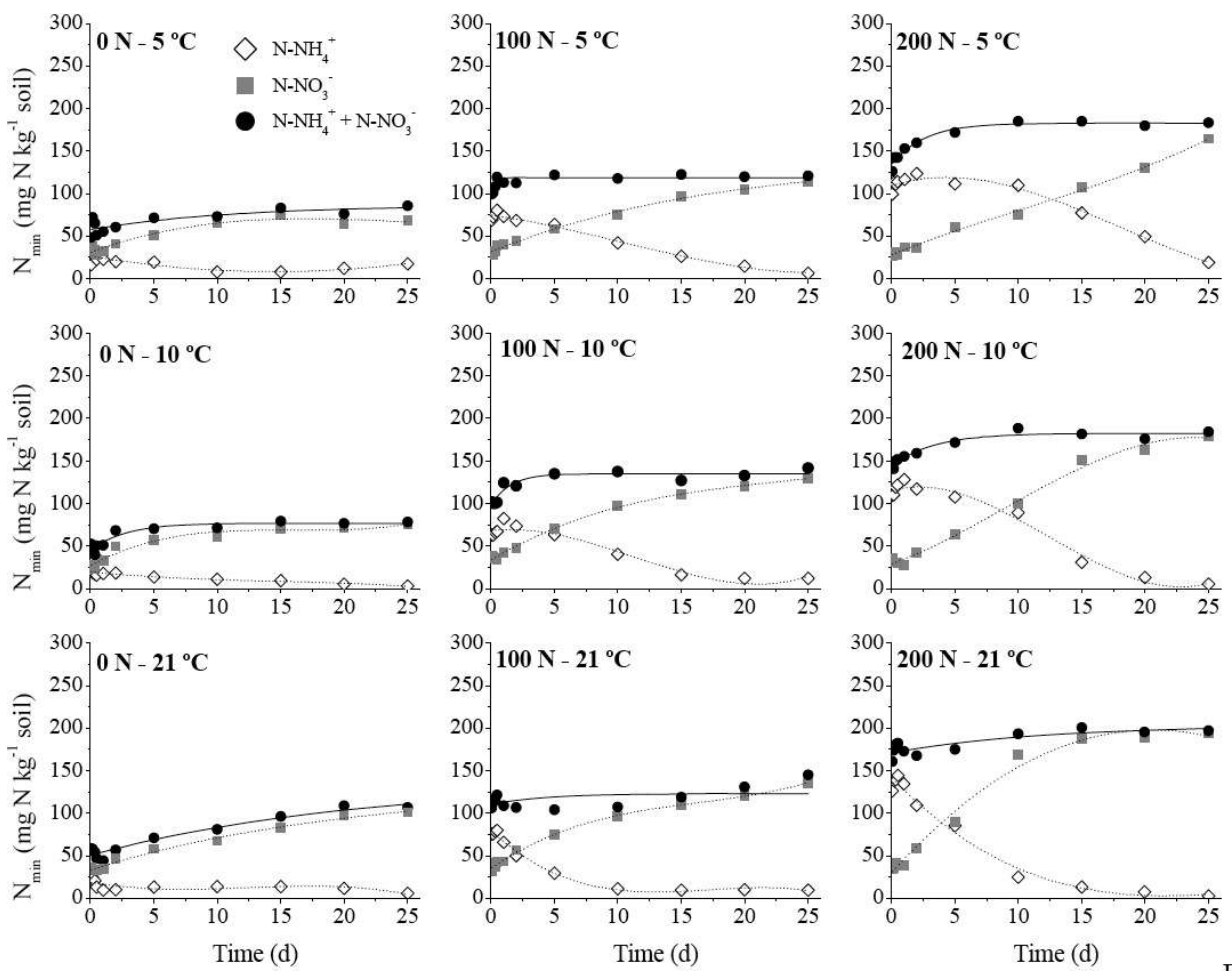

Figure 2: Nitrogen mineralization in Freire soil (FS) during 25 days of incubation at 5 , 10 and $21{ }^{\circ} \mathrm{C}$ and urea input rates equivalent to 0,100 and $200 \mathrm{~kg} \mathrm{~N} \mathrm{ha}^{-1}$.

Figura 2: Mineralización de nitrógeno en el suelo Freire (FS) durante 25 días de incubación a 5,10 y $21^{\circ} \mathrm{C}$ y dosis de aplicación de urea equivalentes a 0,100 y $200 \mathrm{~kg} \mathrm{~N} \mathrm{ha}^{-1}$.

and $\mathrm{NO}_{3}{ }^{-}-\mathrm{N}$ concentration increased steadily at expenses of $\mathrm{NH}_{4}^{+}-\mathrm{N}$, representing between 80 and $96 \%$ of the total mineralized $\mathrm{N}$ at the end of the experiment. In contrast, we observed that 47 to $80 \%$ of mineralized $\mathrm{N}$ remained as $\mathrm{NH}_{4}^{+}-\mathrm{N}$ in PNS for most of the experimental treatments, and a slow increase of the soil $\mathrm{NO}_{3}^{-}-\mathrm{N}$ concentrations was recorded. Such differences in the dynamics of $\mathrm{N}$ transformation between both soils agreed with the $\mathrm{pH}$ fluctuations across the experiment. Thus, a slight increase of $\mathrm{pH}$ was observed in FS at early stages of the incubation by the effect of the ammonification process (equation 1; Figure
5). Later on, soil $\mathrm{pH}$ was reduced about 0.6 units in all treatments due to release of $\mathrm{H}^{+}$ by the nitrification process (equations 2 and 3 ), and the $\mathrm{pH}$ decrease was more apparent at the highest $\mathrm{N}$ amount applied. Likewise, a minor increase of soil $\mathrm{pH}$ was detected in PNS as a consequence of $\mathrm{NH}_{4}^{+}-\mathrm{N}$ formation at the beginning of the incubation study, but not significant $\mathrm{pH}$ changes occurred later. The only exception was the decline up to 1 unit of soil $\mathrm{pH}$ value detected after day 20 at $21{ }^{\circ} \mathrm{C}$ for all $\mathrm{N}$ supply levels. This fact was in accordance with the considerable increase of $\mathrm{NO}_{3}{ }^{-} \mathrm{N}$ concentration by the oxidation of $\mathrm{NH}_{4}^{+}-\mathrm{N}$ in the soil. 

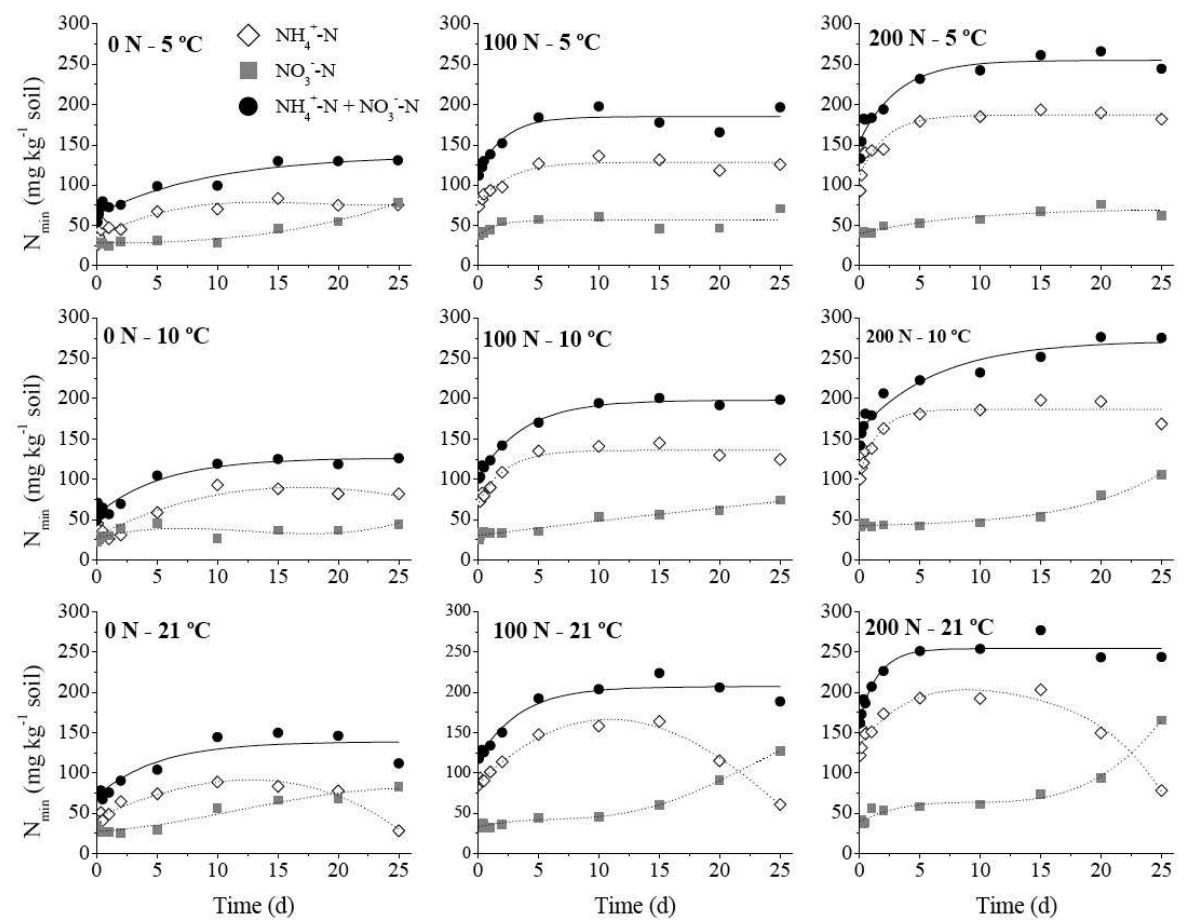

Figure 3: Nitrogen mineralization in Piedras Negras soil (PNS) during 25 days of incubation at 5,10 and $21{ }^{\circ} \mathrm{C}$ and urea input rates equivalent to 0,100 and $200 \mathrm{~kg} \mathrm{~N} \mathrm{ha}^{-1}$.

Figura 3: Mineralización de nitrógeno en el suelo Piedras Negras (PNS) durante 25 días de incubación a 5,10 y $21^{\circ} \mathrm{C}$ y dosis de aplicación de urea equivalentes a 0,100 y 200 $\mathrm{kg} \mathrm{N} \mathrm{ha-1}$.

In agreement with our results, Mora et al. (2007) reported a $\mathrm{pH}$ decrease of about 0.4 units at $0-10 \mathrm{~cm}$ depth as a consequence of a fast nitrification when $300 \mathrm{~kg} \mathrm{~N} \mathrm{ha}^{-1}$ as urea were applied to a pasture growing in an Andisol with chemical properties similar to those of FS. In that study, neither dry matter production nor the forage quality were affected by soil acidity in the shortterm, but an important negative impact of ammonium fertilizers on pasture production was expected in the long-term. Our results showed that in $\mathrm{FS}$ most of $\mathrm{N}$ was mineralized to $\mathrm{NO}_{3}{ }^{-} \mathrm{N}$ at the first day after urea application, and from a practical point of view, it can be inferred that more $\mathrm{N}$ could be potentially lost by leaching through soil profile under field conditions with a negative impact on the environment. Comparatively, nitrification was delayed up to 20-25 days in PNS and this is important because PNS is a representative agricultural Andisol located southernmost than FS. The consequence is that most of $\mathrm{N}$ in PNS could remain as $\mathrm{NH}_{4}{ }^{+}-\mathrm{N}$ free in soil solution or retained by cation exchange on clay and organic matter. As a result, $\mathrm{N}$ leaching losses are minimized and $\mathrm{NH}_{3}$ emissions could be increased in the soil-plant system. Thus, the differences in the inorganic- $\mathrm{N}$ form have a practical significance for pastures and crop management, due to the $\mathrm{N}$ use efficiency of urea fertilizers at a particular location depends on soil chemical and biological properties as well as of the weather conditions. 


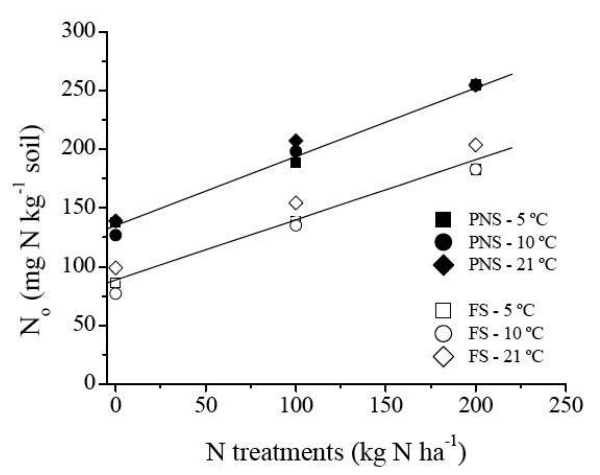

Figure 4: Potentially mineralizable nitrogen $\left(\mathrm{N}_{\mathrm{o}}\right)$ in Freire soil (FS) and Piedras Negras soil (PNS) at different temperatures $(5,10$ and $21^{\circ} \mathrm{C}$ ) and increasing urea supply levels equivalent to field application from 0 to 200 $\mathrm{kg} \mathrm{N} \mathrm{ha}{ }^{-1}$.

Figura 4: Nitrógeno potencialmente mineralizable $\left(\mathrm{N}_{\mathrm{o}}\right)$ en el suelo Freire (FS) y en el suelo Piedras Negras (PNS) a diferentes temperaturas $\left(5,10\right.$ y $\left.21{ }^{\circ} \mathrm{C}\right)$ y niveles crecientes de suministro de urea equivalentes a aplicaciones de campo desde 0 a $200 \mathrm{~kg}$ $\mathrm{N} \mathrm{ha}^{-1}$.
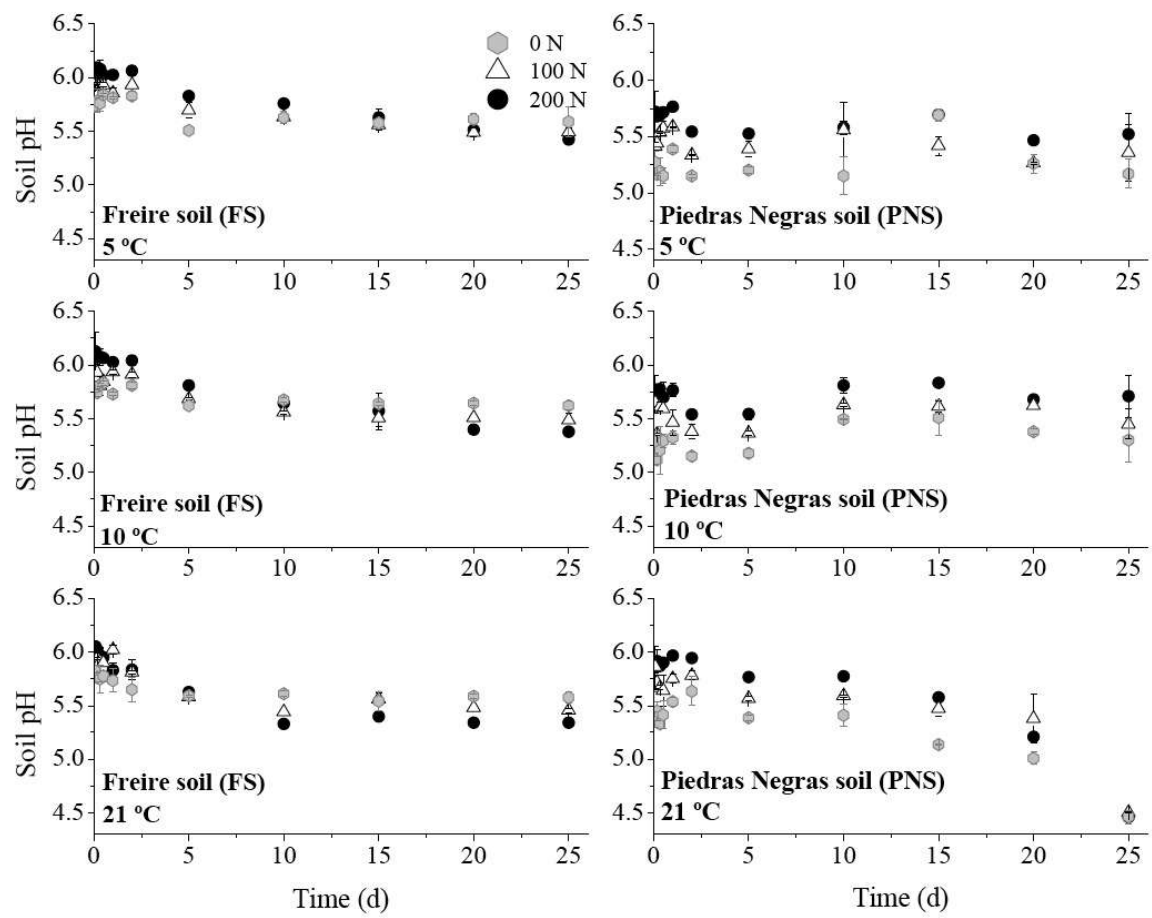

Figure 5: Variation of $\mathrm{pH}$ in Freire soil (FS) and Piedras Negras soil (PNS) during 25 days of incubation at 5,10 and $21^{\circ} \mathrm{C}$ and urea input rates equivalent to 0,100 and 200 $\mathrm{kg} \mathrm{N} \mathrm{ha-1.}$

Figura 5: Variación del pH en el suelo Freire (FS) y en el suelo Piedras Negras (PNS) durante 25 días de incubación a 5,10 y $21{ }^{\circ} \mathrm{C}$ y dosis de aplicación de urea equivalentes a 0,100 y $200 \mathrm{~kg} \mathrm{~N} \mathrm{ha}^{-1}$. 


\section{CONCLUSIONS}

We found that urease activity followed a Michaelis-Menten kinetics in the Andisols evaluated (Freire and Piedras Negras soils). In particular, urease was activated with the increase of temperature and urea supply level, and changes in the kinetics parameters $\left(V_{\max }, K_{m}\right)$ and the catalytic efficiency of the enzyme reaction were directly related with the organic matter content.

In Andisols, the amount of mineralized $\mathrm{N}$ as well as ammonification and nitrification processes seem to be mainly related with the soil organic matter content, temperature and urea supply level. Differences between Freire and Piedras Negras soils in terms of their geographic location generated significant changes in the dynamics of transformation of organic- into inorganic$\mathrm{N}$ forms. This fact has agronomical implications to make decisions on the $\mathrm{N}$ management in pastures and cropping systems. In particular, in Freire soil most of urea was transformed to $\mathrm{NO}_{3}{ }^{-}-\mathrm{N}$ at the first days of the experiment, and therefore, a high amount of $\mathrm{N}$ could be potentially lost by leaching under field conditions. In contrast, in Piedras Negras soil (which is a representative agricultural Andisol located to the south of FS) most of $\mathrm{N}$ remained as $\mathrm{NH}_{4}{ }^{+}-\mathrm{N}$ during the experimental period, which means that $\mathrm{N}$ leaching losses are diminished and $\mathrm{NH}_{3}$ emissions could be increased. Consequently, $\mathrm{N}$ fertilizer recommendations for Andisols must consider not only the amount of $\mathrm{N}$ potentially available for plant growth and timing of $\mathrm{N}$ application, but also weather conditions in order to minimize $\mathrm{N}$ losses either by volatilization or leaching processes in the soil-plant system.

\section{ACKNOWLEDGEMENTS}

This research was supported by FONDECYT projects 1061262, 11080215, 11070241 and by the Bicentenary project of Science and Technology PSD-26 CONICYT-UFRO.

\section{REFERENCES}

Albiach, M.R., Canet, R., Ribó, M., Pomares, F. 2003. Determinación del carbono y nitrógeno de la biomasa microbiana. In: F. Gil-Sotres, T. Hernández Fernández, C. Trasar Cepeda, C. (editors). Técnicas de Análisis de Parámetros Bioquímicos en Suelos: Medida de Actividades Enzimáticas y Biomasa Microbiana. Ediciones Mundi-Prensa, España, p. 245282.

Alfaro, M., Salazar, F. 2005. Ganadería y contaminación difusa, implicancias para el sur de Chile. Agric. Té'5fc. 65, 330340 .

Alfaro, M., Salazar, F., Iraira, S., Teuber, N., Ramírez, L. 2005. Nitrogen runoff and leaching losses in beef production systems under two different stocking rates in Southern Chile. Gayana Bot. 62, 130138.

Alfaro, M.V., Salazar, F.S., Endress, D.B., Dumont J.C.L., Valdebenito, A.B. 2006. Nitrogen leaching losses on a volcanic ash soil affected by the source of fertiliser. J. Soil Sci. Plant Nutr. 6, 54-63.

Antil, R.S., Narwal, R.P., Gupta, A.P. 1992. Urease activity and urea hydrolysis in soils treated with sewage. Ecol. Eng. 1, 229-237.

Blagodatsky, S.A., Yevdokimov, I.V., Larionova, A.A., Richter, J. 1998. Microbial growth in soil and nitrogen turnover: model calibration with laboratory data. Soil Biol Biochem. 30, 1757- 1764.

Cabrera, M.L. 1993. Modeling the flush of nitrogen mineralization caused by drying and rewetting soils. Soil Sci. Soc. Am. J. 57, 63-66.

Cabrera, M.L., Kissel, D.E. 1988. Potentially mineralizable nitrogen in disturbed and undisturbed soil simples. Soil Sci. Soc. Am. J. 52, 1010-1015. 
Cabrera, M.L., Kissel, D.E., Bock, B.R. 1991. Urea hydrolysis in soil: Effects of urea concentration and soil $\mathrm{pH}$. Soil Biol. Biochem. 23, 1121-1124.

Cabrera, M.L., Kissel, D.E., Vigil, M.F. 2005. Nitrogen mineralization from organic residues: Research opportunities. J. Environ. Qual. 34, 75-79.

Camargo, F.A.O., Gianello, C., Tedesco, M.J., Riboldi, J., Meurer, E.J.. Visan, C.A. 2002. Empirical models to predict soil nitrogen mineralization. Ciência Rural 32, 393-399.

Camargo, F.A.O., Gianello, C., Tedesco, M.J. 2004. Soil nitrogen availability evaluated by kinetic mineralization parameters. Commun. Soil Sci. Plant Anal. 35, 1293-1307.

Deans, J.R., Molina, J.A. E., Clapp, C.E. 1986. Models for predicting potentially mineralizable nitrogen and decomposition rate constants. Soil Sci. Soc. Am. J. 50, 323-326.

Dou, Z., Coth, J.D., Jabro, J.D., Fox, R.H., Fritton, D.D. 1996. Soil nitrogen mineralization during laboratory incubation: Dynamics and model fitting. Soil Biol. Biochem. 28, 625-632.

Frankengerberg Jr, W.T., Johanson, J.B., Nelson, C.O. 1983. Urease activity in sewage sludge-amended soil. Soil Biol. Biochem. 15, 543-549.

González, M.S., Novoa, S.A.R., Blaser, G.C. 1995. Preliminary inventory of greenhouse gases in Chile: Agriculture, land-use change and forestry. Revista de la Facultad de Ingeniería de la Universidad Central de Venezuela 10, 130-147.
Han, K.-H., Choi, W.J., Han, G.-H., Yun, S.-I., Yoo, S.-H., Ro, H.-M. 2004. Ureanitrogen transformation and compostnitrogen mineralization in three different soils as affected by the interaction between both nitrogen inputs. Biol. Fertil. Soils 39, 193-199.

Hassink, J. 1997. The capacity of soils to preserve organic $\mathrm{C}$ and $\mathrm{N}$ by their association with clay and silt particles. Plant Soil 191, 77-87.

Jones, A. 1984. Estimation of an active fraction soil nitrogen. Comm. Soil Sci. Plant Anal. 15, 23-32.

Kolberg, R.L., Westfall, D.G., Peterson, G.A. 1999. Influence of cropping intensity and nitrogen fertilizer rates on in situ nitrogen mineralization. Soil Sci. Soc. Am. J. 63, 129-134.

Kumar, V., Wagenet, R.J. 1984. Urease activity and kinetics of urea transformation in soils. Soil Sci. 137, 263-269.

Lemaire, G., Jeuffroy, M.-H., Gastal, F. 2008. Diagnosis tool for plant and crop $\mathrm{N}$ status in vegetative stage. Theory and practices for crop $\mathrm{N}$ managenment. Eur. J. Agron. 28, 614-624.

Mahata, M.K., Antil, R.S. 2004. Effect of organic matter and level of organic carbon on urease activity of selected surface soil contamined with lead. Environ. Ecol. 22, 314-318.

Makkar, H.P.S., Singh, B. 1986. Kinetics of urea hydrolysis and binding of ammonia to wheat straw during ammoniation by urea. J. Dairy Sci. 70, 1313-1317. 
Matus, F.J., Maire, C.R. 2000. Relación entre la material orgánica del suelo, textura del suelo y tasas de mineralización de carbono y nitrógeno. Agric. Téc. 60, 112-126.

Matus, F.J., Rodríguez, J. 1994. A simple model for estimating the contribution of nitrogen mineralization to the nitrogen supply of crops from a stabilized pool of soil organic matter and recent organic input. Plant Soil. 162, 259-271.

Matus, F.J., Lusk, C.H., Maire, C.R. 2008. Effects of soil texture, carbon input rates, and litter quality on free organic matter and nitrogen mineralization in Chilean rain forest and agricultural soils. Commun. Soil Sci. Plant Anal. 39, 187201.

Molina, J.A.E., Clapp, C.E., Larson, W.E. 1980. Potentially mineralizable nitrogen in soil: the simple exponential model does not apply for the first 12 weeks of incubation. Soil Sci. Soc. Am. J. 44, 442443.

Mora, M.L., Ordoñez, C., Cartes, P., Vistoso, E., Pino, J., Jara, A., Demanet, R. 2004. Reciclaje de nitrógeno proveniente de purines en una pastura de Lolium perenne L. In: M.L. Mora (editors), Simposio de las Ciencias del Suelo: Residuos orgánicos y su uso en sistemas agroforestales. Sociedad Chilena de la Ciencia del Suelo. Temuco, Chile. Universidad de La Frontera. p. 243-256.

Mora, M.L., Cartes, P., Núñez, P., Salazar, M., Demanet, R. 2007. Movement of $\mathrm{NO}_{3}{ }^{-} \mathrm{N}$ and $\mathrm{NH}_{4}{ }^{+}-\mathrm{N}$ in an Andisol and its influence on ryegrass production in a short term study. J. Soil Sci. Plant Nutr. 7, 46-64.

Murphy, J., Riley, J.P. 1962. A modified single solution method for phosphate in natural waters, Anal. Chim. Acta 12, 162176.
Nannipieri P, Ceccanti, B. Cervelli, S., Matarese E. 1980. Extraction of phosphatase, urease, protease, organic carbon, and nitrogen from soil. Soil Sci. Soc. Am. J. 44, 1011-1016.

Nieder, R., Benbi, D.K. 2008. Carbon and nitrogen transformations in soils. In: R. Nieder, D.K. Benbi (editors), Carbon and Nitrogen in the Terrestrial Environment. Springer Netherlands, p. 137-159.

Novoa, S.A., González, R., Novoa, S., Rojas, R. 2000. Inventario de gases con efecto invernadero emitidos por la actividad agropecuaria chilena. Agric. Téc. 60, 154165.

Ordoñez, C. 2003. Lixiviación de nitrógeno proveniente de purines en una pastura de Lolium perenne de la IX región y su relación con las curvas de producción, estudio en lisímetros. Tesis de grado Ingeniero Agrónomo, Universidad de La Frontera, Temuco, Chile. 54 p.

Pereira, J., Muniz, J.,Silva, C. 2005. Nonlinear models to predict nitrogen mineralization in an Oxisol. Sci. Agric. (Piracicaba, Braz.) 62, 395-400.

Rasmussen, P.E., Douglas, C.L., Collins, H.P., Albrecht, S.L. 1998. Long-term cropping system effects on mineralizable nitrogen in soil. Soil Biol. Biochem. 30, 1829-1837.

Rodríguez, S.B., Alonso-Gaite, A., ÁlvarezBenedí, J. 2005. Characterization of nitrogen transformations, sorption and volatilization processes in in urea fertilizad soils. Soil Sci. Soc. Am. J. 4, 329-336.

Six, J., Conant, R.T., Paul E.A., Paustian, K. 2002. Stabilization mechanisms of soil organic matter: Implications for Csaturation of soils. Plant Soil 241, 155176. 
Stanford, G., Smith, S.J. 1972. Nitrogen mineralization potentials of soils. Soil Sci. Soc. Am. J. 36, 465-472.

Vance, E., Brookes, P., Jenkinson, D. 1987. An extraction method for measuring soil microbial biomass C. Soil Biol. Biochem. 19, 703-707.

Wang, W.J., Smith, C.J., Chen, D. 2003. Towards a standardised procedure for determining the potentially mineralizable nitrogen of soil. Biol. Fertil. Soils, 37, 362-374.

Advances in study of factors affecting soil $\mathrm{N}$ mineralization in grassland ecosystems. Chin. J. Appl. Ecol. 15, 2184-2188.
Wang, W.J., Smith C.J. and Chen, D. 2004b. Predicting soil nitrogen mineralization dynamics with a modefied double exponential model. Soil Sci. Soc. Am. J. 68, 1256-1265.

Yadav, D.S., Kumar, V., Singh, M., Relan P.S. 1987. Effect of temperature and moisture on kinetics of urea hydrolysis and nitrification. Aust. J. Soil Res. 25, 185-191.

Yan, D.-Z., Wang, D.-J., Sun, R.-J., Lin, J.H. 2006. $\mathrm{N}$ mineralization as affected by long-term $\mathrm{N}$ fertilization and its relationship with crop $\mathrm{N}$ uptake. Pedosphere 16, 125-130. 